\title{
Involvement of the SLIT/ROBO pathway in follicle development in the fetal ovary
}

\author{
Rachel E Dickinson ${ }^{1,2}$, Lynn Hryhorskyj ${ }^{2}$, Hannah Tremewan², Kirsten Hogg ${ }^{2}$, Axel A Thomson ${ }^{1}$, \\ Alan S McNeilly ${ }^{1}$ and W Colin Duncan ${ }^{2}$ \\ ${ }^{1}$ MRC Human Reproductive Sciences Unit and ${ }^{2}$ Division of Reproductive and Developmental Sciences, The Queen's \\ Medical Research Institute, Centre for Reproductive Biology, The University of Edinburgh, 47 Little France Crescent, \\ Edinburgh EH16 4TJ, Scotland, UK \\ Correspondence should be addressed to R E Dickinson at MRC Human Reproductive Sciences Unit, The Queen's Medical Research \\ Institute, Centre for Reproductive Biology, The University of Edinburgh; Email: r.dickinson@hrsu.mrc.ac.uk
}

\begin{abstract}
In humans and domestic mammals, pivotal processes in ovary development, including primordial follicle assembly, occur prenatally. These events are essential for determining fertility in adult life; however, they remain poorly understood at the mechanistic level. In mammals, the SLITs (SLIT1, SLIT2 and SLIT3) and their ROBO (ROBO1, ROBO2, ROBO3/RIG-1 and ROBO4/MAGIC ROBO) receptors regulate neural, leukocyte, vascular smooth muscle cell and endothelial cell migration. In addition, the SLIT/ROBO pathway has functional roles in embryonic development and in the adult ovary by inhibiting cell migration and promoting apoptosis. We therefore characterised follicle formation and investigated the expression and localisation of the ROBO/SLIT pathway in the ovine fetal ovary. Using RT-PCR, we identified SLIT2, SLIT3, ROBO1, ROBO2 and ROBO4 in sheep ovaries harvested across gestation. The real-time quantitative PCR results implied that $\mathrm{ROBO} 2$ expression and $\mathrm{ROBO} 4$ expression were elevated during the early stages of follicle formation and stayed abundant during primordial follicle maturation $(P<0.05)$. Immunohistochemistry examination demonstrated that ROBO1 was localised to the pre-granulosa cells, while ROBO2, ROBO4 and SLIT2 were expressed in the oocytes of the developing primordial follicle. This indicates that in the fetal ovary, SLIT-ROBO signalling may require an autocrine and paracrine interaction. Furthermore, at the time of increased SLIT-ROBO expression, there was a significant reduction in the number of proliferating oocytes in the developing ovary $(P<\mathbf{0 . 0 0 0 1})$. Overall, these results suggest, for the first time, that the SLIT-ROBO pathway is expressed at the time of follicle formation during fetal ovary development.

Reproduction (2010) 139 395-407
\end{abstract}

\section{Introduction}

In most mammals, development of the ovary occurs in utero before birth. Critical events include the successful migration of primordial germ cells (PGCs) along with primordial follicle assembly and development (Loffler \& Koopman 2002). The majority of literature also suggests that in mammals, the number of 'resting' primordial follicles available to the female during her reproductive life is established and fixed before birth (Skinner 2005).

The normal gestation period in sheep lasts 145 days. At days 23-24 of gestation, the gonad is formed through a thickening of the coelomic epithelium, which is located on the mesonephros (McNatty et al. 2000). During this time, a crucial event is the migration of mitotically active PGCs to the genital ridges (McLaren 2000). Sexual differentiation occurs between days 30 and 32 of gestation with the gonad adopting its fate as either a testis or an ovary (Brennan \& Capel 2004). In the ovary, the germ cells divide and cell streams start to develop from somatic cells within the ovarian medulla. These cells intersperse between germ cells creating distinct clusters of oogonia that start to enter meiosis. This occurs between days 40 and 75 of fetal life in the sheep (McNatty et al. 1995).

Another significant period of ovary development is between days 75 and 100 of gestation when follicle formation occurs. On day 75 , the maximal population of PGCs is established with $\sim 850000$ per ovary. From this point onwards, oocytes become arrested in the diplotene stage of meiosis to form the resting pool of primordial follicles. The follicle is formed through the breakdown of germ cell clusters. Subsequently, somatic cells, derived from the cell streams, form a single layer around individual oocytes (McNatty et al. 1995). During this period, there is a massive $80 \%$ reduction in the population of germ cells within the ovary. Throughout the whole process of follicle formation, the oocyte increases in size, as it acquires meiotic and cytoplasmic competence (McNatty et al. 1995). The formation of the 
follicle is therefore imperative for oocyte survival and maintenance of meiotic arrest. Although the events that occur during gestation seem to have such a profound effect on the functional lifespan of the ovary in adulthood, the factors regulating PGC migration and follicle formation require further elucidation.

In Drosophila, the secreted glycoprotein Slit repels migrating neurons during the assembly of the nervous system (Kidd et al. 1999). The actions of Slit are mediated by its receptor, Roundabout (Robo; Seeger et al. 1993). The SLIT-ROBO interaction, and their role in axon guidance, is conserved in mammals, where three Slit (Slit1, Slit2 and Slit3) and four Robo (Robo1, Robo2, Robo3/Rig-1 and Robo4/Magic Robo) genes have been identified (Dickson 2002, Huminiecki et al. 2002). There is also emerging evidence implicating the SLIT/ROBO pathway in cellular processes outside of the nervous system (Wong et al. 2002). SLIT-ROBO signalling seems to inhibit myogenesis, leukocyte chemotaxis and vascular smooth muscle cell migration (Kidd et al. 1999, Wu et al. 2001, Liu et al. 2006). ROBO4 is distinct from the other receptors, playing a specific role in endothelial cell migration (Legg et al. 2008). Furthermore, ROBO1 (3p12), SLIT2 (4p15.2), SLIT3 (5q34-35) and, to a lesser extent, SLIT1 (10q23.3-24) have emerged as candidate tumour suppressor genes that are inactivated through deletions and promoter region hypermethylation in human cancers including cervical tumours (Dickinson et al. 2004, Dallol et al. 2005, Narayan et al. 2006, Singh et al. 2007, Dunwell et al. 2009). The SLIT-ROBO interaction also seems to regulate processes that are pivotal for tumour progression including invasion, metastasis, angiogenesis and apoptosis (Morrissey et al. 2004, Legg et al. 2008, Prasad et al. 2008, Stella et al. 2009).

A role for the SLIT-ROBO pathway in organogenesis has also been suggested as homozygous mutant mice with deletions in one of these genes suffer from severe developmental abnormalities in their lungs, diaphragm, heart, kidneys or brain (Xian et al. 2001, Plump et al. 2002, Liu et al. 2003, Yuan et al. 2003, Grieshammer et al. 2004, Andrews et al. 2008). In addition, we recently demonstrated, for the first time, expression of the SLIT/ROBO pathway in the human adult ovary (Dickinson et al. 2008). Expression of SLIT2, SLIT3 and $\mathrm{ROBO} 2$ increased during the late luteal phase of the corpus luteum and was negatively regulated by hCG and cortisol. Furthermore, blocking SLIT-ROBO activity in luteal cells increased migration and reduced apoptosis, implying a novel role for this system in luteolysis. Interestingly, we also detected expression of SLIT and ROBO family members in the 19-week gestation human fetal ovary.

Overall, these observations indicate that the SLITROBO pathway could be involved in ovary development, perhaps through controlling germ and somatic cell migration or the wave of apoptosis that occurs shortly after mid-gestation. To investigate this intriguing possibility, the aim of the study was to further characterise the critical period for follicle formation in the fetal sheep ovary and examine the expression and localisation of the SLIT/ROBO pathway during this time frame.

\section{Results}

\section{Morphology of the ovary during key stages of gestation}

Haematoxylin and eosin ( $\mathrm{H} \& \mathrm{E})$ staining confirmed that the ovarian morphology changed dramatically between days 50 and 80 of gestation (Fig. 1). At day 50, aggregates of germ cells can be seen, which are not convincingly or predictably associated with neighbouring cells (Fig. 1A). We described this period, where the germ cells are not associated with stromal cells,
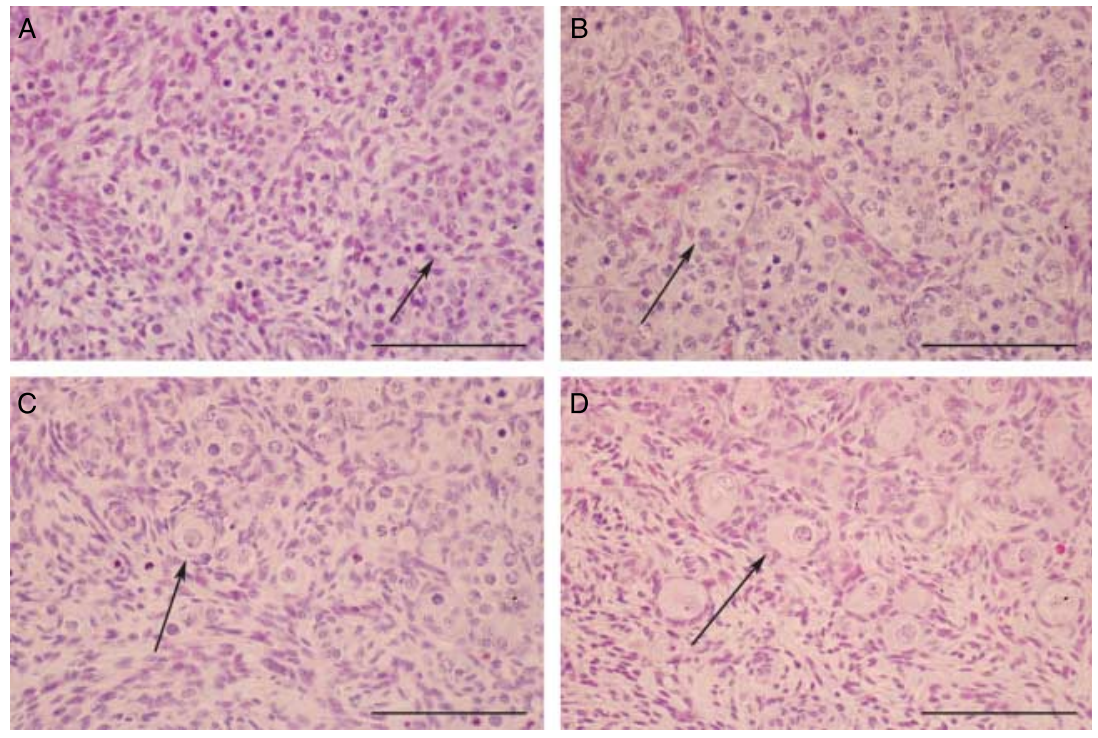

Figure 1 Images of the sheep fetal ovary at key stages of development using an $\mathrm{H} \& \mathrm{E}$ stain. (A) At day 50 (termed Stage 1) of gestation, germ cells were present in clusters (arrow). The germ cell clusters were separated by streams of migrating cells. (B) At day 60 (early Stage 2) of gestation, the germ cells were more distinctive (arrow). (C) Early primordial follicle formation was seen by day 70 (late Stage 2) with the breakdown of germ cell clusters and the somatic cells surrounding individual oocytes (arrow). (D) Primordial follicles were more distinct at day 80 (Stage 3) (arrow). An increased number of pre-granulosa cells were associated with the oocyte and had formed a clear single layer around the oocyte. All the scale bars represent $100 \mu \mathrm{m}$. 
as 'Stage 1 '. The first fully formed primordial follicles were observed at day 80 with pre-granulosa cells becoming associated with the oocyte (Fig. 1D). This period, with clearly formed follicles, was categorised as 'Stage 3'. The intense period of stromal migration and follicle formation appeared to occur between days 60 and 70 . We classified this period as 'Stage 2'. Firstly, clear germ cell clusters and stromal cell streams developed. Consequently, the germ cell clusters broke down and there was an increased association between the oocytes and stromal cells (Fig. 1C). Therefore, at these three stages of gestation, there are distinct differences in the cell migration and tissue remodelling that is occurring in the ovary. Next, we characterised cell proliferation, programmed cell death and germ cell maturation during these three critical stages of ovary development.

\section{Immunolocalisation of cell markers during ovary development}

The number of proliferating cells at the different stages of ovarian development was assessed using immunohistochemistry to determine Ki67 expression (Fig. 2). This antibody has been used in previous studies as a marker for cell proliferation in the developing ovary (Balla et al. 2008). There was intense Ki67 staining in the germ cell clusters, while the surrounding somatic cells showed weaker expression. Furthermore, Ki67 expression changed significantly across gestation $(P<0.0001$, KruskalWallis test). Expression of Ki67 was maximal at Stage 1, and significantly reduced in Stage 2 and Stage 3 of gestation by 6 - to 7.5 -fold $(P<0.0001$, Dunn's multiple comparison test; Fig. 2F).

The SLIT/ROBO pathway is thought to promote apoptosis through activation of caspase-3 (Morrissey et al. 2004, Dickinson et al. 2008). Since cell proliferation changed across gestation, the number of cells undergoing caspase-dependent apoptosis was also assessed using immunohistochemistry for cleaved (activated) caspase-3 (Fig. 3). Specific immunopositive cells could be detected at each key stage, and there was a trend towards a reduction in cleaved caspase-3 staining in Stage 2 and Stage 3 of gestation, compared with Stage 1 $(P=0.079$, Kruskal-Wallis test; Fig. 3E). However, in Stage 2 and Stage 3 of gestation cleaved caspase- 3 seemed to be localised to pyknotic germ cells within ovigerous cords (Fig. 3B and C). At Stage 1 of gestation, the cleaved caspase-3 staining was not germ cell specific (Fig. 3A).

As OCT-3/4 (also known as POU class 5 homeobox 1 (POU5F1)) is a germ cell marker that changes during maturation, its expression was also investigated by immunohistochemistry across the different stages of ovary development (Fig. 4). Previous studies have used this antibody as a marker for pluripotent germ cells in the developing human ovary (Anderson et al. 2007). POU5F1 expression increased significantly with gestational age $(P<0.01$, Kruskal-Wallis test). The number of POU5F1 immunopositive cells was significantly 28-fold higher at Stage 3 compared with Stage 1.
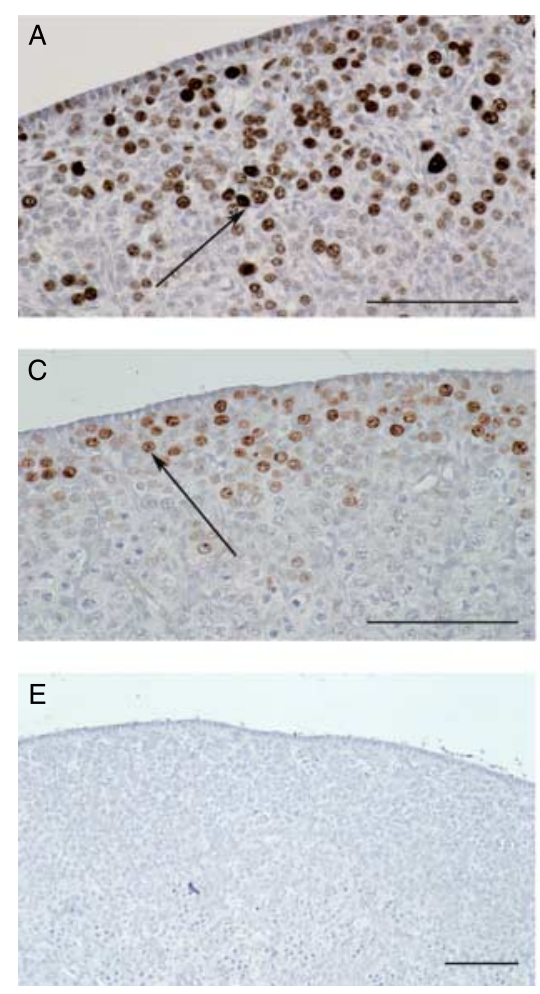

www.reproduction-online.org
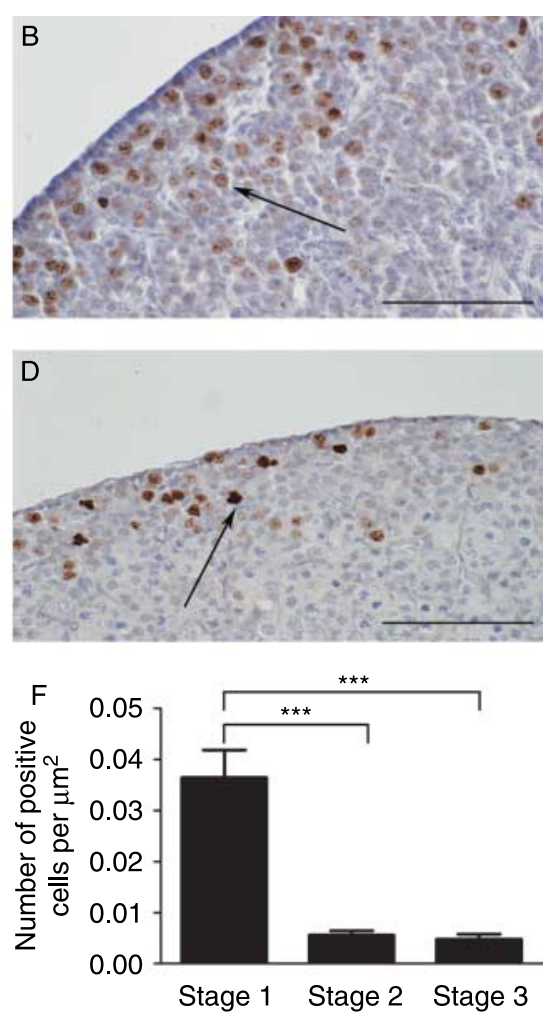

Figure 2 Localisation of proliferating cells throughout sheep gestation using Ki67 as a marker. (A) Light-field microscopy revealed intense brown DAB staining for Ki67 in the germ cells of day 50 (Stage 1) ovaries. As gestational age increases, there was a reduction in positive brown DAB staining. Decreased Ki67 expression was observed in the germ cells of Stage 2 (B and C) and Stage 3 (D) ovaries. Arrows are pointing at oocytes showing positive brown DAB staining. (E) No DAB staining was observed in the negative control section. All the scale bars represent $100 \mu \mathrm{m}$. (F) To quantify the results, the total number of Ki67positive cells was counted over 8-12 fields for each ovary. This number was divided by the total area of $8-12$ fields $\left(2000-3000 \mu \mathrm{m}^{2}\right)$ to give the number of cells per $\mu \mathrm{m}^{2}$ for each ovary. For this experiment, three Stage 1, eight Stage 2 and four Stage 3 ovaries were examined for Ki67 staining. Values are the mean for each group \pm s.E.M. Ki67 expression changed significantly across gestation $(P<0.0001$, Kruskal-Wallis test). There was a significant reduction in the number of Ki67positive cells at Stage 2 and Stage 3 of gestation compared with Stage 1 ( $P<0.0001$, Dunn). 

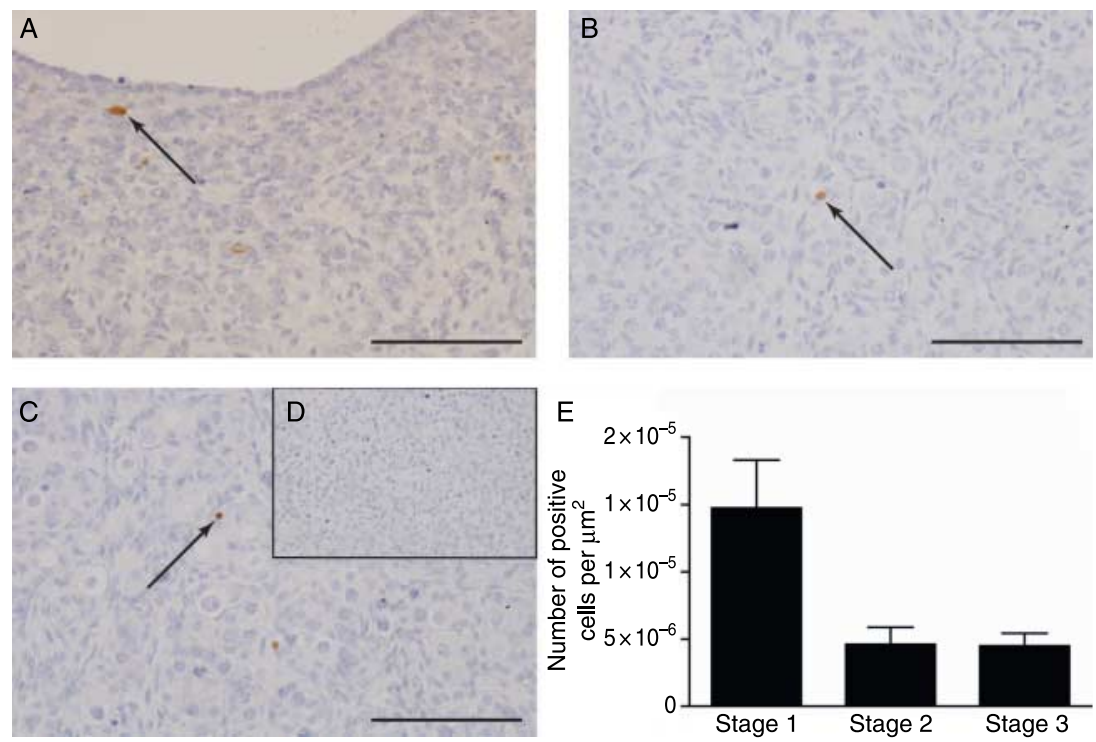

Figure 3 The asssessment of caspase-3-dependent apoptosis over sheep gestation. (A) Light-field microscopy revealed intense brown DAB staining for cleaved caspase- 3 in the germ cells of Stage 1 ovaries. Decreased cleaved caspase- 3 expression was noted in the germ cells of Stage 2 (B) and Stage 3 (C) ovaries. Black arrows are pointing at oocytes showing positive brown DAB staining. (D) No DAB staining was observed in the negative control section. All the scale bars represent $100 \mu \mathrm{m}$. (E) To quantify the results, the total number of activated caspase-3 positive cells were counted over 8-12 fields for each ovary. This number was divided by the total area of 8-12 fields (2000-3000 $\left.\mu \mathrm{m}^{2}\right)$ to give the number of cells per $\mu \mathrm{m}^{2}$ for each ovary. For this experiment, three Stage 1, eight Stage 2 and four Stage 3 ovaries were examined for cleaved caspase-3 staining. Values are the mean for each group \pm s.E.M. Expression of activated caspase-3 did not change significantly across gestation $(P>0.05$, Kruskal-Wallis test).

Furthermore, the staining seemed to be confined to more mature oocytes associated with somatic cells and not in the germ cell clusters $(P<0.0001$, Dunn's multiple comparison test; Fig. 4F).

These findings confirm that each of the categorised developmental stages is associated with specific events. Stage 1 involves germ cell proliferation, while Stage 2 is associated with stromal cell migration and follicle formation. Stage 3 is associated with formed follicles and germ cell maturation. If the SLIT/ROBO pathway has a role in ovarian development, we hypothesised that they would be expressed in the fetal ovary and the expression would be differentially regulated between the three disparate stages.

\section{Members of the SLIT and ROBO families are expressed in the fetal ovary}

Therefore, a cohort of sheep fetal ovary RNA samples was used to investigate whether expression of the SLIT/ROBO pathway plays a novel role in these pivotal stages of ovarian development. The expression of each $R O B O$ and SLIT gene transcript was examined at different gestational stages using RT-PCR (Fig. 5). ROBO3 and SLIT1 were not expressed in the sheep ovary throughout adult and fetal life (data not shown). However, ROBO1, ROBO2, ROBO4, SLIT2 and SLIT3 were expressed not only in the adult ovary but also throughout gestation, suggesting that they may have a role in the development of this organ.

\section{$\mathrm{ROBO} 2$ and $\mathrm{ROBO} 4$ are differentially expressed across gestation}

Real-time quantitative PCR was used to assess whether expression of ROBO1, ROBO2, ROBO4, SLIT2 and SLIT3 was differentially regulated in the ovary during gestation (Fig. 6). $\mathrm{ROBO} 2$ and $\mathrm{ROBO} 4$ expression changed significantly across the developmental stages $(P<0.01$ and $P<0.05$ respectively, ANOVA; Fig. 6B and $C)$. There was a five- to six-fold increase in $\mathrm{ROBO} 2$ expression at Stage 2 and Stage 3 of gestation compared with Stage $1 \quad(P<0.01$ and $P<0.05$ respectively, Bonferonni's multiple comparison test). Expression of $\mathrm{ROBO} 4$ was also significantly twofold higher in Stage 2 compared with Stage 1 of gestation $(P<0.05$, Bonferonni's multiple comparison test). ROBO4 expression was maintained during Stage 3 of development but was not significantly higher than at Stage 1. During developmental growth, there was also a trend towards an increase in $R O B O 1$ expression during Stage 2 of gestation ( $P=0.1406$, ANOVA; Fig. 6A). ROBO1 mRNA did seem to be more abundant than other members of the SLIT and ROBO families. Expression of SLIT2 and SLIT3 showed more variation within the samples and did not change notably throughout gestation (Fig. 6D and E). These results indicate that during ovary development, the SLIT/ROBO pathway is regulated at the receptor level. Furthermore, the expression of SLITs and ROBOs seems to be elevated during the stage of follicle development, rather than that of germ cell proliferation. 

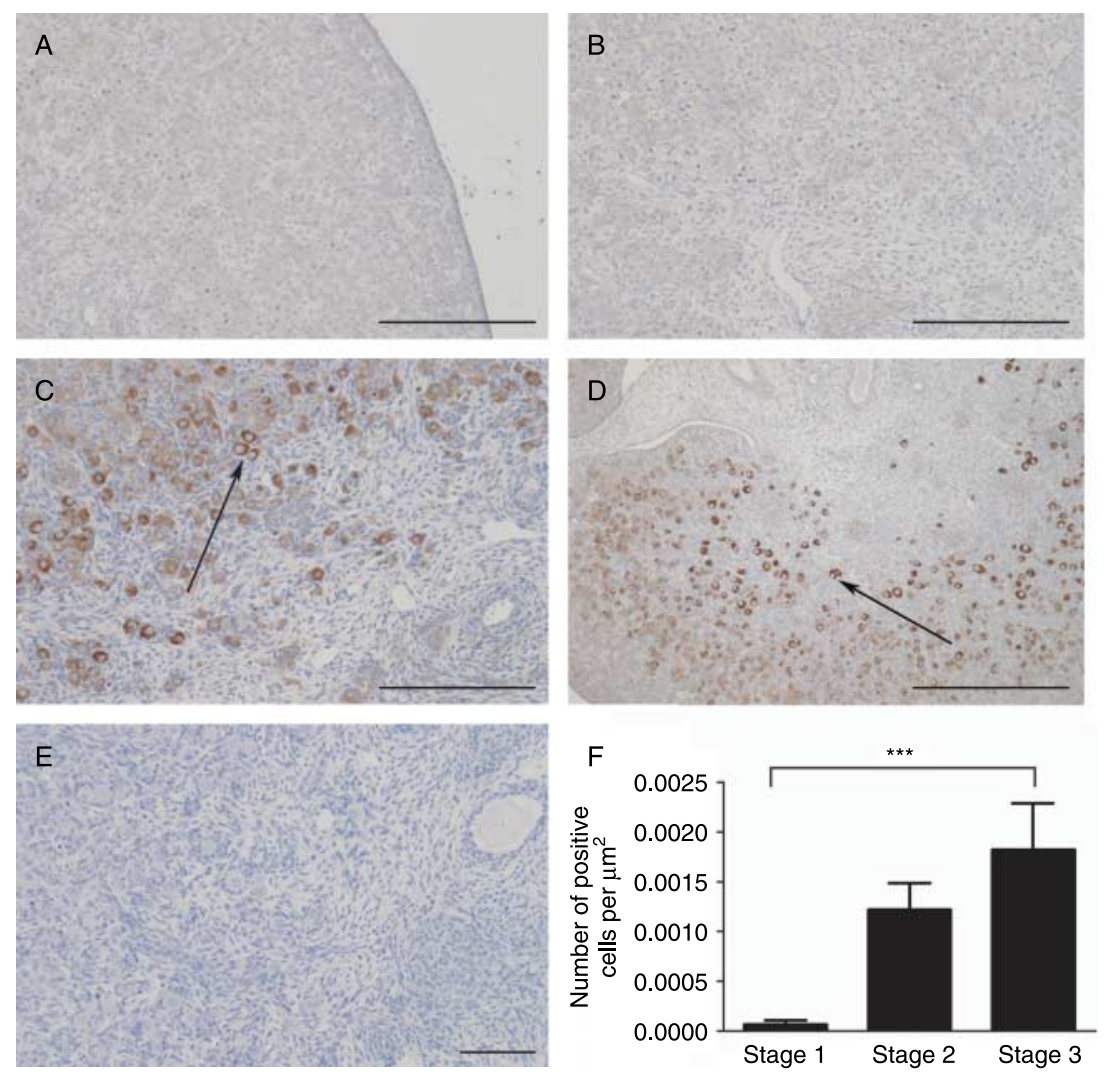

Figure 4 Using the pluripotency marker POU5F1 (OCT-3/4), the number of germ cells increased with sheep gestation. (A) Light-field microscopy of a Stage 1 ovary showing no weak brown DAB staining for POU5F1. (B) An early Stage 2 ovary still had low levels of POU5F1 expression. (C) A late Stage 2 ovary had more prominent positive brown POU5F1 staining. (D) By Stage 3 of gestation, there was intense positive brown DAB staining for POU5F1. Arrows are pointing at oocytes showing positive brown DAB staining. (E) A negative control section had no DAB staining. All the scale bars represent $100 \mu \mathrm{m}$. (F) To quantify the results, the number of POU5F1 positive cells was counted over 8-12 fields for each ovary. This number was divided by the total area of $8-12$ fields (2000-3000 $\mu \mathrm{m}^{2}$ ) to give the number of cells per $\mu \mathrm{m}^{2}$ for each ovary. For this experiment, three Stage 1, eight Stage 2 and four Stage 3 ovaries were examined for POU5F1 staining. Values are the mean for each group \pm S.E.M. There was a direct correlation between gestational age and POU5F1 expression $(P<0.01$, Kruskal-Wallis test). There was a significantly higher number of POU5F1 positive cells in Stage 3 ovaries compared with Stage $1(P<0.0001$, Dunn).

\section{Immunolocalisation of ROBO and SLIT in the fetal ovary}

In order to determine which cell types express members of the SLIT/ROBO pathway, the proteins were localised by immunohistochemistry. ROBO1 immunohistochemistry was performed to investigate whether the mRNA expression pattern in the fetal ovary was maintained at the protein level (Fig. 7A-D). Results showed clear and specific ROBO1 immunostaining at Stage 3 of gestation with weak expression at Stage 2 and little protein expression at Stage 1. ROBO1 was localised primarily to the pre-granulosa cells of the follicle with some staining of the oocyte. This would be consistent with a role in the forming follicle. As no ROBO1 blocking peptide was available, immunoblotting was performed to confirm that the antibody was specific. Previous research has suggested that the ROBO1 protein is around $181 \mathrm{kDa}$ and is expressed in fetal liver tissue but not in the adult liver (Ito et al. 2006). Immunoblot analysis confirmed the expression of a 181-kDa protein in the protein lystate from two sheep fetal liver samples but not a lamb liver tissue (Fig. 7D). Since $\mathrm{ROBO} 2$ and $\mathrm{ROBO} 4 \mathrm{mRNA}$ expression changed across gestation, immunohistochemistry for these two proteins was also performed (Figs 7E-H and 8 respectively). Sections from Stage 3 of gestation showed more intense $\mathrm{ROBO} 2$ staining in the oocytes of forming primordial follicles (Fig. 7G). Intense ROBO4 expression was apparent around blood vessels, pre-granulosa cells and oocytes. This was more evident in Stage 2 and Stage 3 of gestation, which coincides with early primordial follicle development (Fig. 8B and C).

Using immunohistochemistry, the ligand, SLIT2, was also localised to the forming follicle in the fetal ovary (Fig. 7I-L). Weak SLIT2 staining was apparent from Stage 2

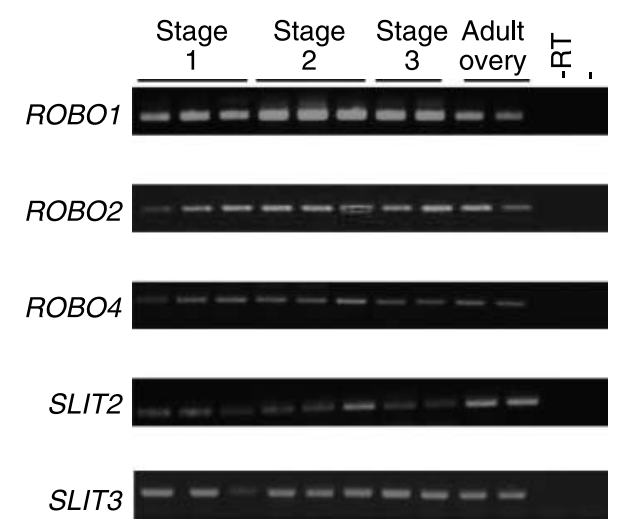

Figure 5 The SLIT and $R O B O$ gene families were expressed in the sheep ovary. RNA extracted from Stage 1, Stage 2 and Stage 3 fetal ovaries as well as two adult sheep ovaries was used as a template for RT-PCR. At all stages of development, the sheep fetal ovary expressed $R O B O 1$, ROBO2, ROBO4, SLIT2 and SLIT3. The adult sheep also expressed these genes. Negative control samples containing PCR master mix without any DNA (-) or RNA, which had not been converted to cDNA $(-\mathrm{RT})$ showed no expression suggesting the results were not due to genomic DNA contamination. 

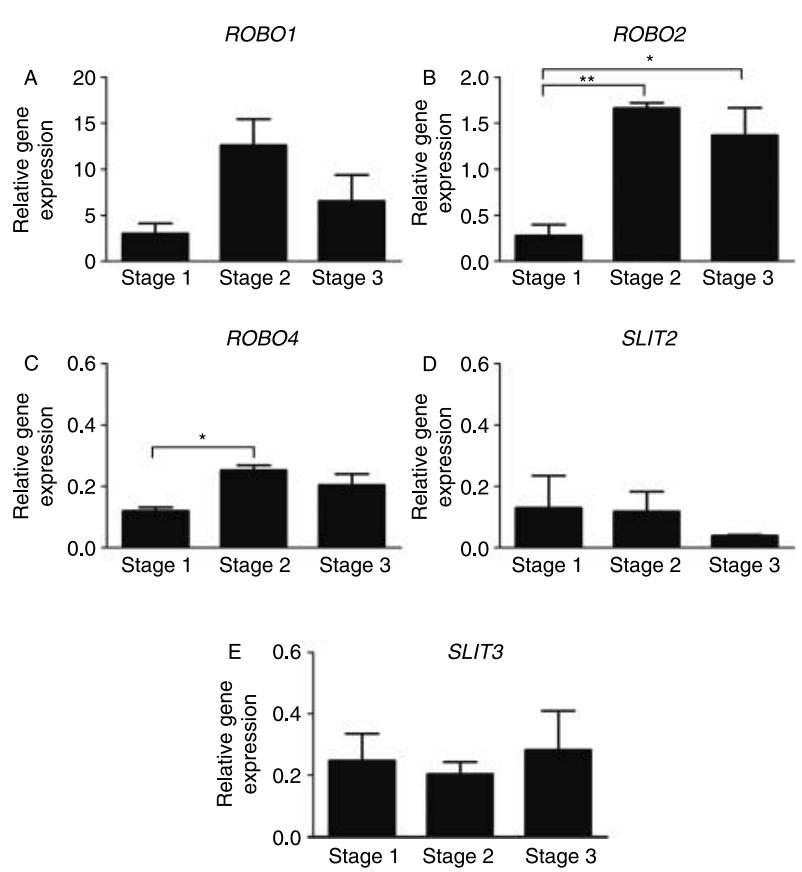

Figure 6 Expression of SLIT and $R O B O$ genes across gestation using real-time quantitative PCR. (A) $R O B O 1$ expression peaked at Stage 2 of gestation; however, the trend was nonsignificant $(P>0.05$, ANOVA). (B) $R O B O 2$ expression changed significantly across gestation in the ovary $(P<0.01, \mathrm{ANOVA})$. There was a significant increase in $\mathrm{ROBO} 2$ expression at Stage 2 and Stage 3 of gestation compared with Stage 1 $(P<0.01$ and $P<0.05$ respectively, Bonferonni). (C) Likewise, expression of $\mathrm{ROBO} 4$ also changed across sheep gestation. $\mathrm{ROBO} 4$ expression was significantly higher in Stage 2 compared with Stage 1 ovaries $(P<0.05$, Bonferonni). ROBO4 was maintained at elevated expression levels in Stage 3 ovaries, but the value was not significantly different than at Stage 1. (D) SLIT2 expression showed high variation between samples and did not change significantly across gestation $(P>0.05$, ANOVA). (E) Similarly, expression of SLIT3 also did not change significantly over the developmental stages ( $P>0.05$, ANOVA). The expression data shown was normalised to the GAPDH expression level. However, the same trends, and similar relative expression values, were observed when HPRT1 was used as a housekeeping gene instead (data not shown). ROBO1, SLIT2 and SLIT3 expression did not change across gestation ( $P>0.05$, ANOVA). At Stage 2 of development, ovaries exhibited higher expression levels of $\mathrm{ROBO} 2$ and $\mathrm{ROBO} 4$, and this was maintained throughout Stage 3 as well $(P<0.05$, ANOVA).

of gestation with expression confined to the germ cell clusters. SLIT2 was predominantly expressed in the oocytes with only a little light staining in the pre-granulosa cells. This staining pattern in the forming primordial follicles was more marked by Stage 3 of development. Overall, these findings suggest that the SLIT/ROBO pathway is active during primordial follicle formation and may act in an autocrine or paracrine fashion.

\section{Discussion}

Key events that culminate in a fertile healthy ovary occur during fetal life in humans and domestic species. However, the molecular and cellular mechanisms that underpin these pivotal processes have yet to be fully elucidated (McNatty et al. 2000). Therefore, research in this area is of critical importance. Along with an evolutionary conserved role in axon guidance, the SLIT/ ROBO pathway has a key function during organogenesis (Piper et al. 2000). Our previous research indicated that expression of SLIT2, SLIT3 and ROBO2 was regulated during the lifespan of the human corpus luteum (Dickinson et al. 2008). These studies also suggested that the SLITs and ROBOs regulate apoptosis and cell migration in the human adult ovary, processes that occur during development of this organ as well (Dickinson et al. 2008). This report investigated, for the first time, expression of the SLITs and ROBOs during sheep fetal ovary development. The study also further characterised the period of follicle formation, during sheep fetal ovary development, by quantifying the number of proliferating and apoptotic cells along with oocytes.

The $\mathrm{H} \& \mathrm{E}$ staining results supported previous fetal sheep ovary studies (McNatty et al. 1995, 2000). At day 50 of gestation, nests of oocytes were observed. Between days 60 and 70 of gestation, there were early signs of follicle assembly. Firstly, the germ cell clusters started to become associated with neighbouring stromal cell streams. Subsequently, individual oocytes were surrounded by an incomplete layer of pre-granulosa cells. By day 80 of gestation, the first fully formed primordial follicles were perceived.

Female germ cells are expected to stop proliferating prior to their entry into meiosis, which occurs around day 65-75 in sheep gestation (McNatty et al. 2000, Rae et al. 2002). Using Ki67 as a proliferation marker, in our sheep fetal ovaries, the majority of dividing cells were oocytes. As predicted, the number of proliferating sheep oocytes also declined dramatically as gestational age increased (Fig. 2F). Interestingly, some Ki67-positive germ cells were detected in Stages 2 and 3 ovaries, supporting human, mouse and cow studies (Wrobel et al. 1996, Traut et al. 2002, Stoop et al. 2005). Therefore, Ki67 may have a role in meiosis as well as mitosis and might be an unreliable cell proliferation marker. An alternative marker could have been used but previous studies using proliferating cell nuclear antigen (PCNA) also detected positive cells during later stages of sheep fetal ovary development (Rae et al. 2001). These may have been non-cycling cells as well since PCNA also regulates DNA repair pathways and has a long half-life (Lea et al. 2006). Therefore, a robust marker for the end of the oocyte mitosis phase still needs to be developed.

The SLIT-ROBO pathway can inhibit the proliferation of cortical neurons (Andrews et al. 2008). Furthermore, SLIT-ROBO signalling increases breast cancer cell death along with promoting apoptosis in colorectal tumour, lung tumour and luteal ovarian cells potentially through a caspase-3-mediated mechanism (Dallol et al. 2002, 2003, Morrissey et al. 2004, Dickinson et al. 2008). An increase in oocyte apoptosis has been noted during day 75-90 of sheep gestation when primordial follicle 

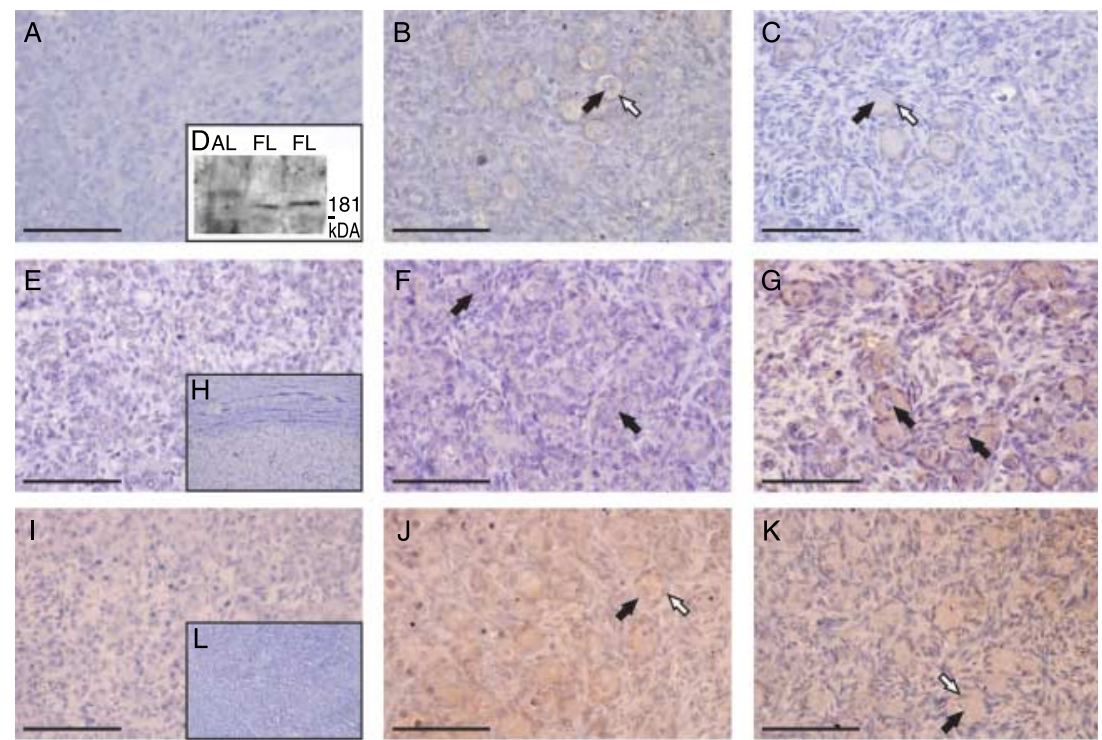

Figure 7 Expression and localisation of ROBO1, ROBO2 and SLIT2 throughout gestation. (A) Light-field microscopy of a Stage 1 ovary showing no positive brown DAB staining for ROBO1. Light-field microscopy of Stage 2 (B) and Stage 3 (C) ovaries showing ROBO1 staining around the pregranulosa cells of developing primoridal follicles. At no point was the positive staining observed in the migrating cells. Black arrows are pointing towards the oocytes. The pre-granulosa cells are highlighted by white arrows. (D) Immunoblot analysis of ROBO1 clarifying the specificity of the antibody. As expected, a 181-kDa protein was detected in the total protein lysate from two fetal liver samples (FL) but not in a lamb liver sample (AL). (E) Weak positive brown DAB staining for ROBO2 was detected in Stage 1 ovaries using light-field microscopy. (F) Some ROBO2 staining was noted in Stage 2 ovaries around germ cell clusters and early primordial follicles. (G) The oocytes of developing primordial follicles showed intense positive brown staining in Stage 3 of gestation. Black arrows are pointing towards the oocytes. $(\mathrm{H}) \mathrm{A}$ negative control serial section contained no ROBO2 staining. (I) No positive brown DAB staining for SLIT2 was noted in Stage 1 ovaries by light-field microscopy. (J) Positive SLIT2 expression was observed in early primordial follicles of Stage 2 ovaries. (K) Weak SLIT2 staining was detected in the oocytes and pre-granulosa cells of developing primordial follicles at Stage 3 of gestation. Black arrows are pointing towards oocytes. Pre-granulosa cells are highlighted by white arrows. (L) A negative control section showed no SLIT2 staining. All the scale bars represent $100 \mu \mathrm{m}$.

assembly begins (Sawyer et al. 2002). Interestingly, human oocytes appear to undergo apoptosis at the corresponding stage of gestation, and this is associated with an increase in caspase- 3 activity (Fulton et al. 2005). Therefore, we hypothesised that during Stage 2 of gestation, at the time of early folliculogenesis, there would be elevated caspase-3 activity. Unexpectedly, while active caspase-3 staining was detected in the pyknotic oocytes of primordial follicles at Stage 2 of gestation, a larger number of positive cells were noted in Stage 1 ovaries. However, in Stage 1 ovaries, the cleaved caspase- 3 staining was not oocyte specific. Caspase- 3 is also expressed transiently, so some apoptotic cells may have been undetected by immunohistochemistry. In addition to apoptosis, mechanisms associated with mitotic arrest may also contribute to germ cell loss in the developing ovary (Wartenberg et al. 2001). Whether a SLIT/ROBO-mediated cell cycle arrest occurs during primordial follicle formation requires further elucidation. However, previous research has suggested that this pathway can regulate cell division in human breast tumour and Drosophila neural precursor cells (Mehta \& Bhat 2001, Dickinson et al. 2005).

In species such as mice, the POU5F1 transcription factor is considered to be a marker of pluripotency (Kehler et al. 2004). Previous work in the human ovary has also suggested that, since POU5F1 staining can be detected during oogenesis but not in germ cells involved in folliculogenesis, this undifferentiated state is lost at the onset of meiosis (Stoop et al. 2005). Therefore, POU5F1 positive staining should cease after day $65-75$ of sheep gestation. Surprisingly, at Stage 3 of development, around day 80 of gestation, we observed an increase in POU5F1 positive cells. Interestingly, oocytes within mouse primordial and primary follicles also maintain POU5F1 expression (Pesce et al. 1998). Furthermore, in domestic species, including cows and pigs, POU5F1 expression has been detected in non-pluripotent cells of the developing embryo (Kirchhof et al. 2000). Therefore, POU5F1 expression is not evolutionary conserved within different species. We would like to examine POU5F1 staining in ovaries from sheep at earlier and later gestations to characterise ovine germ cell maturation in more detail, but unfortunately these materials were not available for our study.

Our results implied that the sheep ovary expresses, at the RNA and protein level, most members of the SLIT and ROBO families during all stages of gestation. We also demonstrated that the adult sheep ovary expresses SLIT2, SLIT3, ROBO1, ROBO2 and ROBO4. Overlapping expression patterns for the Slits and Robos were noted during vertebrate chick limb 

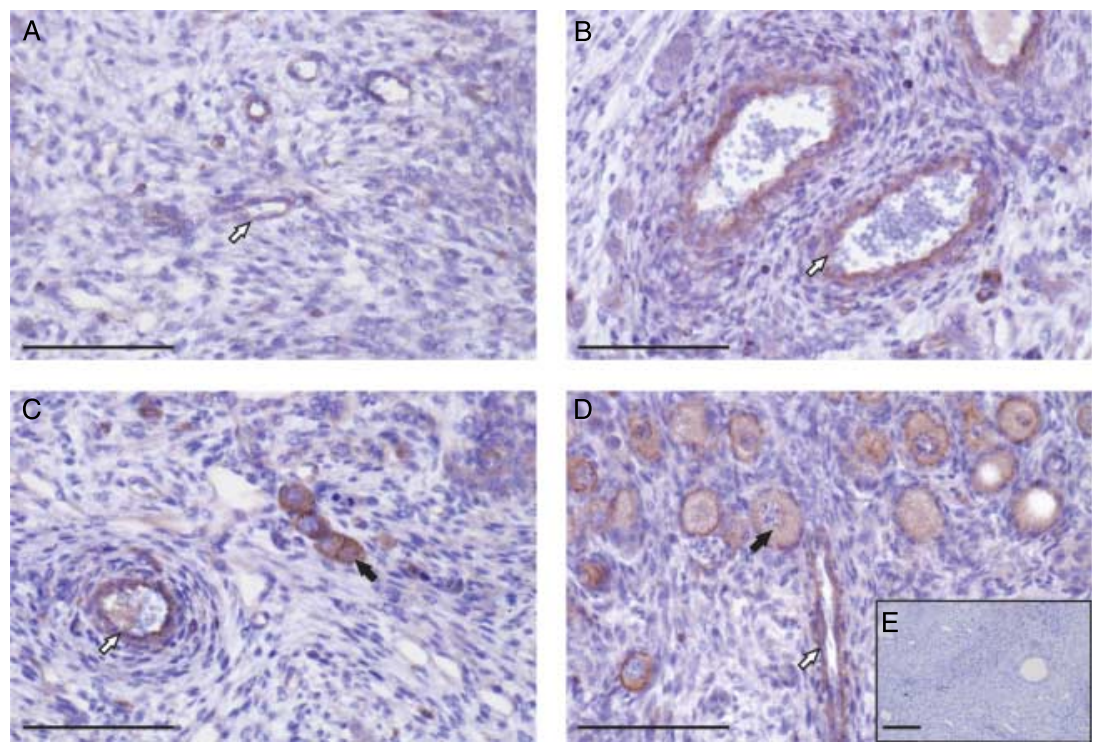

Figure 8 ROBO4 immunostaining and localisation across gestation. (A) Using light-field microscopy, weak ROBO4 expression (positive brown DAB staining) was detected around the blood vessels of Stage 1 ovaries. (B) At Stage 2 of gestation, increased $\mathrm{ROBO} 4$ expression around the vasculature was observed. (C) Positive brown DAB staining was also noted around oocytes of developing primordial follicles at Stage 2 of gestation. (D) The oocytes of more mature primordial follicles and blood vessels contained intense ROBO4 expression (dark brown DAB staining) at Stage 3 of development. White arrows are pointing towards blood vessels. Oocytes are emphasised by black arrows. (E) No DAB staining was observed in a negative control serial section. All the scale bars represent $100 \mu \mathrm{m}$. development (Piper et al. 2000, Vargesson et al. 2001). However, in these studies, the in situ hybridisation results were not quantified, so it was not clear whether individual Slits and/or Robos were differentially expressed over development. Intriguingly, our data suggest that while transcript levels of the SLIT ligands did not change across gestation, $\mathrm{ROBO} 2$ and $\mathrm{ROBO} 4$ expression did change significantly. Expression of both genes increased during the time of follicle formation and was maintained while the primordial follicles were developing. Our real-time quantitative PCR results indicated that $R O B O 1$ is the most abundant SLIT/ROBO family member at the mRNA level. When either GAPDH or HPRT1 was used as the housekeeping gene, $R O B O 1$ expression was around ninefold higher than $\mathrm{ROBO} 2$ and 35 -fold higher than ROBO4, SLIT2 and SLIT3. Like ROBO2 and ROBO4, $R O B O 1$ mRNA expression also increased from Stage 1 to Stage 2 of development, although it was a nonsignificant trend. Therefore, at the time of reduced germ cell proliferation, there is increased $R O B O$ expression, providing further evidence that these genes may have a role in the loss of oocytes that occurs during ovary development. Furthermore, it is the ROBO receptor, and not the SLIT ligand, that is temporally regulated in the fetal ovary. Interestingly, in the adult human ovary, both the receptor and the ligand showed differential expression over the lifespan of the corpus luteum (Dickinson et al. 2008). In head and neck squamous cell carcinoma and normal tissue, ROBO1 and ROBO2 protein expression corresponded with the mRNA results (Ghosh et al. 2009). Although our immunohistochemistry results were not quantified, expression of ROBO1, $\mathrm{ROBO} 2$ and $\mathrm{ROBO} 4$ proteins seemed to increase with gestational age. Additionally, while $R O B O 1$ seems to be the most abundant $R O B O$ transcript, the immunohistochemistry results indicate that $\mathrm{ROBO} 2$ and $\mathrm{ROBO} 4$ are more highly expressed at the protein level. There was little ROBO1 staining in particularly Stage 1 ovaries. These results suggest that there could be post-transcriptional regulation of ROBOs during fetal sheep ovary development. Alternatively, these findings may be due to a time delay in translation after the production of $R O B O$ transcripts. Actually, we cannot fully compare the staining intensity of the different antibodies, as they were not raised against sheep $\mathrm{ROBO}$ proteins. While the antibodies did react with the corresponding proteins, they may have been working sub-optimally and have different binding abilities.

Immunohistochemistry examination demonstrated that, in the developing primordial follicle, ROBO1 was predominantly localised to pre-granulosa cells, while $\mathrm{ROBO} 2$ and SLIT2 were primarily distributed in the oocytes. ROBO4 is considered an unusual ROBO receptor, as it is mainly expressed in the vasculature where it regulates endothelial cell migration (Legg et al. 2008). Unsurprisingly, we noted ROBO4 expression in the blood vessels of the ovary across sheep gestation. Interestingly, ROBO4 expression was also detected in the oocytes, suggesting that this receptor may function outside of the vascular system. Overall, the localisation data imply that SLIT/ROBO signalling involves an autocrine and paracrine interaction, which also occurs during Drosophila heart and kidney development (Piper et al. 2000, Helenius \& Beitel 2008). The SLIT2 immunostaining was diffuse but this is typical of secreted proteins. The antibody we used detected SLIT2 in glioblastoma cells (Mertsch et al. 2008). This antibody seems to be specific for the protein as we followed their immunoblotting protocol and identified a single 140$\mathrm{kDa}$ band, corresponding to the $\mathrm{N}$-terminal fragment of 
SLIT2, in the protein lysate from two sheep fetal liver samples (data not shown). The potential role of the SLIT/ ROBO pathway in the breakdown of the germ cell clusters and the formation of primordial follicles was not investigated in this study. Since the majority of Slit/Robo mutant mice die at birth due to a variety of organ defects, they cannot be used to examine follicle development since this event occurs postnatally in rodents (Andrews et al. 2007). No models with inactive Slits/Robos, in solely reproductive tissues, have been reported.

To conclude, this research has demonstrated, for the first time, expression of the SLIT-ROBO pathway during fetal ovary development. These preliminary results suggest that the SLITs and ROBOs could influence processes that occur during early ovary development such as follicle formation or oocyte survival. Further research should be undertaken to address these theories and confirm the importance of this pathway in, potentially, the female reproductive lifespan.

\section{Materials and Methods \\ Collection of sheep ovaries}

The ovarian cycles of Scottish grey-face ewes were synchronised using progesterone sponges. Following the removal of sponges, the ewes were mated and pregnancy was detected using ultrasonography. The sheep were kept under standard conditions of lighting and temperature and slaughtered under schedule on requirement. This research was part of a project that has undergone ethical and home office review. For immunohistochemical analysis, ovaries were collected from three fetal sheep on day 50 , five on day 60 , three from day 70 and four from day 80 . We were guided by literature describing day 75-90 of gestation in sheep as the period of follicle formation (Tisdall et al. 1999). Originally, we were going to cluster the ovaries by gestational age and have four groups: day 50; day 60; day 70 and day 80 . The H \& E staining indicated that day 50 and day 80 ovaries had distinct morphology. However, the morphology of day 60 and day 70 ovaries was not well-defined. In fact, some day 60 and day 70 ovaries were similar to one another and had varied morphology. Therefore, we grouped day 60 and 70 ovaries together to give three disparate and absolutely morphologically distinct phases of follicular assembly. For simplicity, they were named Stage 1 (day 50), Stage 2 (day 60-70) and Stage 3 (day 80) respectively. Ovaries were fixed in Bouin's and embedded in paraffin wax. Sections of $5 \mu \mathrm{m}$ were cut and then mounted on poly-L-lysinecoated microscope slides. Adult sheep ovaries from pregnant sheep were also collected and used as positive controls. Ovaries from three Stage 1, three Stage 2 and four Stage 3 fetal sheep were also frozen at $-70{ }^{\circ} \mathrm{C}$ for RNA extraction. Again they were named Stage 1, 2 and 3 respectively. Total RNA was extracted from the ovaries using the RNesy Mini kit (Qiagen Ltd) according to the manufacturer's instructions. All RNAs was DNase treated with on column DNase I (Qiagen Ltd).

\section{Expression analysis}

Extracted RNA from frozen sheep ovary tissue was used as a template for cDNA synthesis using Taqman RT reagents (Applied Biosystems, Warrington, UK) according to the manufacturer's instructions. Primers used for PCR were designed using Primer3 software (http://frodo.wi.mit.edu/ primer3/) from DNA sequences obtained at Ensembl Genome Browser (http://www.ensembl.org/index.html). Since the sheep sequences for the SLIT and ROBO genes have not been described yet, primers were designed based on the cow sequence. To minimise the amplification of genomic DNA, the forward and reverse primers for each gene were specific for different exons. Primers were synthesised by MWG-AG Biotech (Milton Keynes, UK) and are described in Table 1. PCR was performed on an Eppendorf Mastercycler gradient authorised thermocycler (Perkin-Elmer, Inc., Waltham, MA, USA) using GoTaq Flexi DNA polymerase (Promega Ltd). The PCR thermocycle consisted of an initial denaturation of $5 \mathrm{~min}$ at $95{ }^{\circ} \mathrm{C}$ followed by 35 cycles of $95^{\circ} \mathrm{C}$ for $30 \mathrm{~s}$, annealing

Table 1 Primers used in the expression and real-time quantitative PCR analyses of candidate genes.

\begin{tabular}{|c|c|c|c|c|c|c|}
\hline Gene & $\begin{array}{l}\text { Primer } \\
\text { locations } \\
\text { (exons) }\end{array}$ & Primer sequence $\left(5^{\prime}-3^{\prime}\right)$ & $\begin{array}{l}\mathrm{MgCl}_{2} \\
(\mathrm{mM})\end{array}$ & $\begin{array}{l}\text { Annealing } \\
\text { temperature }\left({ }^{\circ} \mathrm{C}\right)\end{array}$ & $\begin{array}{l}\text { Product } \\
\text { size }(b p)\end{array}$ & $\begin{array}{l}\text { Percentage of homology } \\
\text { between sheep and cow } \\
\text { sequenced PCR products }\end{array}$ \\
\hline SLIT2 & $\begin{array}{l}\text { (F) } 36 \\
\text { (R) } 37\end{array}$ & $\begin{array}{l}\text { TGGAGGTGTCСТCTGTGATG } \\
\text { TTATCСTTTCСССТCGACAA }\end{array}$ & 1.5 & 54 & 173 & 97 \\
\hline SLIT3 & $\begin{array}{l}\text { (F) } 10 \\
\text { (R) } 12\end{array}$ & $\begin{array}{l}\text { GGAGCCTTCACCCAGTACAA } \\
\text { ACACCAGCCCATCAAACAGT }\end{array}$ & 1.5 & 60 & 166 & 96 \\
\hline ROBO1 & $\begin{array}{l}\text { (F) } 12 \\
\text { (R) } 13\end{array}$ & $\begin{array}{l}\text { TTGAATTCAGGAGCAACTCC } \\
\text { ATTAGCTGCCCTCACAAGGC }\end{array}$ & 1.5 & 57 & 161 & 100 \\
\hline ROBO2 & $\begin{array}{l}\text { (F) } 6 \\
\text { (R) } 7 \& 8\end{array}$ & $\begin{array}{l}\text { CTGAGAATCGGGTTGGAAAA } \\
\text { AGGTTCTGGCTGCCTTCTTT }\end{array}$ & 1.5 & 57 & 181 & 94 \\
\hline $\mathrm{ROBO} 4$ & $\begin{array}{l}\text { (F) } 2 \\
\text { (R) } 3\end{array}$ & $\begin{array}{l}\text { TGTGAGGCCAGCAACCGGCT } \\
\text { GTGGGCTCTGGGTGGCCCCA }\end{array}$ & 1.5 & 60 & 164 & 100 \\
\hline GAPDH & $\begin{array}{l}\text { (F) } 6 \\
\text { (R) } 8\end{array}$ & $\begin{array}{l}\text { GGCGTGAACCACGAGAAGTAT } \\
\text { AAGCAGGGATGATGTTCTGG }\end{array}$ & 1.5 & 60 & 153 & $\mathrm{~N} / \mathrm{A}$ \\
\hline
\end{tabular}

The annealing temperatures listed were used for standard expression analysis. These sheep PCR products were sequenced and compared with the known cow SLIT2, SLIT3, ROBO1, ROBO2 and ROBO4 nucleotide sequences. The percentage of homology between the sheep sequenced PCR products and corresponding cow sequence were then calculated using the ClustalW program (www.ebi.ac.uk). The annealing temperature used for real-time quantitative PCR was $60^{\circ} \mathrm{C}$ for all primer pairs. 
temperature for $30 \mathrm{~s}, 72{ }^{\circ} \mathrm{C}$ for $30 \mathrm{~s}$ and a final extension of 10 min at $72{ }^{\circ} \mathrm{C}$. PCR products were visualised on a $2 \%$ agarose gel with added ethidium bromide. Products were purified using a gel extraction kit (Qiagen Ltd) and sequenced to confirm their identity. The sequenced PCR products were then compared with the known cow sequences using the ClustalW program at www.ebi.ac.uk. The percentage of homology between the sheep and cow sequenced PCR products is reported in Table 1.

\section{Real-time quantitative PCR}

RNA was extracted and reverse transcribed as described above. A standard curve was also generated with serial dilutions of cDNA synthesised from sheep adult ovary total RNA (Stratagene Europe, Amsterdam, The Netherlands). Real-time quantitative PCR amplification was then performed in duplicate $10-\mu$ l reactions using Platinum SYBR Green qPCR SuperMIX-UDG (Invitrogen Ltd) following the manufacturer's instructions and using the $\mathrm{ABI} 7900 \mathrm{HT}$ Fast Real Time PCR system instrument (Applied Biosystems). Primers used were the same as for the expression analysis and are described in Table 1 . The cycling program consisted of an initial UDG incubation of $2 \mathrm{~min}$ at $50^{\circ} \mathrm{C}$ and then a denaturation step for $2 \mathrm{~min}$ at $95^{\circ} \mathrm{C}$. This was followed by 45 cycles of $95^{\circ} \mathrm{C}$ for $15 \mathrm{~s}$, $60{ }^{\circ} \mathrm{C}$ for $10 \mathrm{~s}$ and $72{ }^{\circ} \mathrm{C}$ for $30 \mathrm{~s}$. The default setting for the $\mathrm{ABI}$ instrument was used for the melting curve analysis.

The ABI analysis software calculated quantitative values for each sample by comparing the sample threshold cycle $\left(C_{t}\right)$ number, where the increase in the signal associated with exponential growth of PCR products begins to be detected, to the standard curve, according to the manufacturer's manuals. In all cases, the level of gene expression within the samples lay within the boundaries of the corresponding standard curve. Since the precise quality and amount of cDNA that was added to each reaction mix was difficult to assess, transcripts of sheep glyceraldehyde-3-phosphate dehydrogenase $(G A P D H)$, a housekeeping gene, were also quantified for each sample as described above. Each sample was normalised on the basis of its GAPDH content by dividing the amount of target gene by the amount of housekeeping gene. To confirm that GAPDH is not regulated in the samples under investigation and therefore is a suitable endogenous control, each sample was also normalised on the basis of its hypoxanthine phosphoribosyltransferase (HPRT1) content. Previous research using sheep fetal ovary cDNA across gestation had used HPRT1 as a housekeeping gene for SYBR Green real-time quantitative PCR (Baillet et al. 2008).

\section{Haematoxylin and eosin staining}

First, sections were dewaxed in xylene, rehydrated in ethanol and rinsed in water. To stain basophilic structures, including the nuclei, blue-purple sections were placed in haematoxylin for $30 \mathrm{~s}$. Acid alcohol was then used to lighten the staining outside of the nucleus. Next, sections were washed in slightly alkaline Scott's tap water to increase the blue colour. The cytoplasm of cells was then stained pink with eosin for 20 s. Finally, sections were washed in water, dehydrated in ethanol, fixed in xylene and mounted using the appropriate coverslip.

\section{Immunohistochemistry}

First, sections were dewaxed, rehydrated, washed in PBS, subjected to pressure cooker antigen retrieval in $0.01 \mathrm{M}$ citric acid ( $\mathrm{pH} \mathrm{6.0)}$ for $5 \mathrm{~min}$ and left to cool to room temperature. Next, all sections were washed and placed in $3 \% \mathrm{H}_{2} \mathrm{O}_{2} / d_{d d H_{2}} \mathrm{O}$ for $10 \mathrm{~min}$ to block any endogenous peroxidase activity. Sections that were going to be incubated with ROBO1, ROBO2, ROBO4 and SLIT2 antibodies were given an additional avidin and biotin block. All sections were then further blocked using the suitable normal serum (Diagnostics Scotland, Edinburgh, UK) diluted in TBS for $1 \mathrm{~h}$ at room temperature. Sections were then incubated with primary antibodies, diluted in appropriate normal serum, for $16-24 \mathrm{~h}$ at $4{ }^{\circ} \mathrm{C}$. This was

Table 2 Antibodies used for immunohistochemistry.

\begin{tabular}{|c|c|c|c|c|c|}
\hline Antibody & Antigen & Concentration & Isotype & Species & Source \\
\hline SC-16619 & $\begin{array}{l}\text { Human SLIT2 (E-20) } \\
\text { internal region }\end{array}$ & $20 \mu \mathrm{g} / \mathrm{ml}$ & Polyclonal & Goat & $\begin{array}{c}\text { Santa Cruz Biotechnology, Insight } \\
\text { Biotechnology, Middlesex, UK }\end{array}$ \\
\hline AF1749 & $\begin{array}{l}\text { Rat ROBO1 extracellular } \\
\text { domain 19-560 }\end{array}$ & $10 \mu \mathrm{g} / \mathrm{ml}$ & Polyclonal & Goat & R\&D Systems, Inc., Abingdon, UK \\
\hline SC-16615 & $\begin{array}{l}\text { Human } \mathrm{ROBO} 2 \text { (C 20) } \\
\text { internal region }\end{array}$ & $20 \mu \mathrm{g} / \mathrm{ml}$ & Polyclonal & Goat & $\begin{array}{c}\text { Santa Cruz Biotechnology, Insight } \\
\text { Biotechnology, Middlesex, UK }\end{array}$ \\
\hline ab10547 & $\begin{array}{l}\text { Human ROBO4 residues } \\
\text { 300-400 }\end{array}$ & $10 \mu \mathrm{g} / \mathrm{ml}$ & Polyclonal & Rabbit & Abcam, Cambridge, UK \\
\hline $9664 S$ & $\begin{array}{l}\text { Human cleaved caspase-3 } \\
\qquad(\text { Asp 175) (5A1) }\end{array}$ & 1 in100 & Monoclonal & Rabbit & $\begin{array}{l}\text { Cell Signalling, New England } \\
\text { Biolabs, Hitchin, UK }\end{array}$ \\
\hline NCL-Ki67-MM1 & Human Ki67 & $10 \mu \mathrm{g} / \mathrm{ml}$ & Monoclonal $\operatorname{lgG}_{1}$ & Mouse & $\begin{array}{l}\text { Novocastra Laboratories, Vision } \\
\text { Systems, Newcastle, UK }\end{array}$ \\
\hline SC-8629 & $\begin{array}{l}\text { Human OCT-3/4 (POU5F1) (C 20) } \\
\text { C-terminus }\end{array}$ & $1 \mu \mathrm{g} / \mathrm{ml}$ & Polyclonal & Goat & $\begin{array}{c}\text { Santa Cruz Biotechnology, Insight } \\
\text { Biotechnology, Middlesex, UK }\end{array}$ \\
\hline BA-5000 & Goat immunoglobulins & $3 \mu \mathrm{g} / \mathrm{ml}$ & $\begin{array}{l}\text { Polyclonal } \\
\text { biotinylated }\end{array}$ & Rabbit & $\begin{array}{l}\text { Vector Laboratories Inc., } \\
\text { Peterborough, UK }\end{array}$ \\
\hline E0432 & Rabbit immunoglobulins & $1.52 \mu \mathrm{g} / \mathrm{ml}$ & $\begin{array}{l}\text { Polyclonal } \\
\text { biotinylated }\end{array}$ & Goat & $\begin{array}{l}\text { Vector Laboratories Inc., } \\
\text { Peterborough, UK }\end{array}$ \\
\hline E0433 & Mouse immunoglobulins & $1.52 \mu \mathrm{g} / \mathrm{ml}$ & $\begin{array}{l}\text { Polyclonal } \\
\text { biotinylated }\end{array}$ & Goat & Dako UK Ltd, Ely, UK \\
\hline
\end{tabular}


followed by washes with PBS on an orbital shaker. Sections were then incubated at room temperature for $1 \mathrm{~h}$ with the suitable biotinylated secondary antibody diluted in the appropriate normal serum. After washing, as before, the sections were incubated in avidin-biotin complex HRP (Dako UK Ltd, Ely, Cambridgeshire, UK) for $1 \mathrm{~h}$. Binding was visualised by subsequent incubation with liquid 3,3'-diaminobenzidine tetra-hydrochloride (Dako). Sections were counterstained lightly with haematoxylin to enable cell identification. Since non-specific binding of an antibody to proteins other than the antigen can sometimes occur, negative control experiments were conducted where the SLIT2, ROBO2, ROBO4 and cleaved caspase- 3 antibodies were neutralised by incubating them in a 2-10 times excess of peptide for either $30 \mathrm{~min}$ at room temperature or overnight at $4{ }^{\circ} \mathrm{C}$. The neutralised antibody was then used side-by-side with the antibody alone, and the results were compared. As blocking peptides for ROBO1, POU5F1 and Ki67 were unavailable, negative controls for those experiments were performed in parallel using an identical protocol except primary antibody was replaced with blocking serum containing non-specific immunoglobulins at the same concentration. Negative controls and slides with different primary antibodies were washed separately in PBS to reduce the risk of contamination. Images were captured using an Olympus Corp. Provis microscope (Olympus Corp. Optical Co., London, UK) equipped with a Kodak DCS330 camera (Eastman Kodak Co.), stored on a HP computer and assembled using Photoshop 7.0.1 (Adobe). See Table 2 for the list of antibodies used and appropriate techniques.

\section{Immunoblotting}

Protein lysates were prepared from two fetal sheep liver and one lamb liver tissue with a lysis buffer composed of 9-M urea, $50 \mathrm{mM}$ Tris- $\mathrm{HCl}(\mathrm{pH} \mathrm{7.5)}$ and $0.15 \mathrm{M} \beta$-mercaptoethanol as described (Xian et al. 2001). Protein concentration was determined using the Bradford assay (Bio-Rad Laboratories Ltd), and $20 \mu \mathrm{g}$ of lysate was subjected to SDS-PAGE on a $7.5 \%$ polyacrylamide gel. Protein was then transferred onto a Hybond-P PVDF membrane (GE Healthcare UK Ltd, Buckinghamshire, UK) for $2 \mathrm{~h}$ and probed with an anti-ROBO1 antibody, described in Table 2, at $0.4 \mu \mathrm{g} / \mathrm{ml}$. Signals were detected using HRP-conjugated chicken anti-goat IgG (Insight Biotechnology, Middlesex, UK) at $0.2 \mu \mathrm{g} / \mathrm{ml}$ and visualised by enhanced chemiluminescence (GE Healthcare UK Ltd). After analysis, membranes were stained with India ink to allow the total composition of protein in each sample to be assessed.

\section{Cell scoring}

Cell scoring was performed on all Ki67 and POU5F1 and caspase-3 immunohistochemical results by an observer that was blinded to the tissue identity. A stratified randomised sampling technique was used to select fields. The number of positive cells was counted in each field using a microscope at $\times 40$ objective and a cell counter. For each ovary, 12 fields were counted, with the exception of ovaries from day 50 of gestation, which only provided enough tissue for eight fields.
The area of one field at $\times 40$ objective was noted, using a haemocytometer, as $250 \mu \mathrm{m}^{2}$. This was multiplied by 12 , or 8 in the case of day 50 ovaries, to give the total area. The number of cells per $\mu \mathrm{m}^{2}$ for each ovary was then calculated by dividing the total number of positive cells by the total area.

\section{Statistical analysis}

Statistical analyses were carried out on raw data from real-time quantitative PCR after confirmation of normal distributions for parametric analysis with a one-way ANOVA since more than two groups were compared. When group means were significantly different by ANOVA, pairwise comparisons were performed using Bonferronni's multiple comparison test. Raw data from cell scoring did not show a normal distribution so a non-parametric Kruskal-Wallis test was performed. Dunn's multiple comparison test was used when group means were significantly different by Kruskal-Wallis test. All statistical tests are highlighted in the figure legends, and differences are given either $* P<0.05 ;{ }^{* *} P<0.01$; or ${ }^{* * *} P<0.001$. Differences were considered significant at $P<0.05$.

\section{Declaration of interest}

The authors declare no conflict of interest that could be perceived as prejudicing the impartiality of the research reported.

\section{Funding}

The work was supported by the Medical Research Council (grant number R39757). Dr Rachel Dickinson is supported by a Medical Research Council Career Development Fellowship.

\section{Acknowledgements}

The authors would like to thank Joan Docherty and the staff of the Marshall Building, Edinburgh, UK for help in sheep maintenance and ovary collection. In addition, we appreciate the technical advice and support of Eva Gay and Sheila MacPherson.

\section{References}

Anderson RA, Fulton N, Cowan G, Coutts S \& Saunders PT 2007 Conserved and divergent patterns of expression of DAZL, VASA and OCT4 in the germ cells of the human fetal ovary and testis. BMC Developmental Biology 7136.

Andrews WD, Barber M \& Parnavelas JG 2007 Slit-Robo interactions during cortical development. Journal of Anatomy 211 188-198.

Andrews W, Barber $M$, Hernadez-Miranda LR, Xian J, Rakic S, Sundaresan V, Rabbitts TH, Pannell R, Rabbitts P, Thompson H et al. 2008 The role of Slit-Robo signaling in the generation, migration and morphological differentiation of cortical interneurons. Developmental Biology 313 648-658.

Baillet A, Mandon-Pepin B, Cabau C, Poumerol E, Pailhoux E \& Cotinot C 2008 Identification of transcripts involved in meiosis and follicle formation during ovine ovary development. BMC Genomics 9436.

Balla M, Angelopoulou R, Lavranos G \& Kittas C 2008 Follicular cells versus oocytes: cell population dynamics in the developing ovary. Tissue \& Cell 40 373-381. 
Brennan J \& Capel B 2004 One tissue, two fates: molecular genetic events that underlie testis versus ovary development. Nature Reviews. Genetics 5 509-521.

Dallol A, Da Silva NF, Viacava P, Minna JD, Bieche I, Maher ER \& Latif F 2002 SLIT2, a human homologue of the Drosophila Slit2 gene, has tumor suppressor activity and is frequently inactivated in lung and breast cancers. Cancer Research 62 5874-5880.

Dallol A, Morton D, Maher ER \& Latif F 2003 SLIT2 axon guidance molecule is frequently inactivated in colorectal cancer and suppresses growth of colorectal carcinoma cells. Cancer Research 63 1054-1058.

Dallol A, Dickinson RE \& Latif F 2005 Epigenetic disruption of the SLITROBO interactions in human cancer. In DNA Methylation, Epigenetics and Metastasis, vol 7, pp. 191-214. Ed M Esteller. Dorvecht, The Netherlands: Springer.

Dickinson RE, Dallol A, Bieche I, Krex D, Morton D, Maher ER \& Latif F 2004 Epigenetic inactivation of SLIT3 and SLIT1 genes in human cancers. British Journal of Cancer 91 2071-2078.

Dickinson RE, Dallol A, Maher ER \& Latif F 2005 Molecular and functional analysis of the SLIT2 gene in breast cancer (abstract). In Proceedings of the 96th Annual Meeting of the American Association of Cancer Research, Apr 2005, Anaheim, CA. Philadelphia (PA): AACR, p 659. Abstract 2799.

Dickinson RE, Myers M \& Duncan WC 2008 Novel regulated expression of the SLIT/ROBO pathway in the ovary: possible role during luteolysis in women. Endocrinology 149 5024-5034.

Dickson BJ 2002 Molecular mechanisms of axon guidance. Science 298 1959-1964.

Dunwell TL, Dickinson RE, Stankovic T, Dallol A, Weston V, Austen B, Catchpoole D, Maher ER \& Latif F 2009 Frequent epigenetic inactivation of the SLIT2 gene in chronic and acute lymphocytic leukemia. Epigenetics 4 265-269.

Fulton N, Martins da Silva SJ, Bayne RA \& Anderson RA 2005 Germ cell proliferation and apoptosis in the developing human ovary. Journal of Clinical Endocrinology and Metabolism 90 4664-4670.

Ghosh S, Ghosh A, Maiti GP, Alam N, Roy A, Roychoudhury S \& Panda CK 2009 Alterations of ROBO1/DUTT1 and ROBO2 loci in early dysplastic lesions of head and neck: clinical and prognostic implications. Human Genetics 125 189-198.

Grieshammer U, Le M, Plump AS, Wang F, Tessier-Lavigne M \& Martin GR 2004 SLIT2-mediated ROBO2 signaling restricts kidney induction to a single site. Developmental Cell 6 709-717.

Helenius IT \& Beitel GJ 2008 The first 'Slit' is the deepest: the secret to a hollow heart. Journal of Cell Biology 182 221-223.

Huminiecki L, Gorn M, Suchting S, Poulsom R \& Bicknell R 2002 Magic roundabout is a new member of the roundabout receptor family that is endothelial specific and expressed at sites of active angiogenesis. Genomics 79 547-552.

Ito H, Funahashi S, Yamauchi N, Shibahara J, Midorikawa Y, Kawai S, Kinoshita Y, Watanabe A, Hippo Y, Ohtomo T et al. 2006 Identification of ROBO1 as a novel hepatocellular carcinoma antigen and a potential therapeutic and diagnostic target. Clinical Cancer Research 12 3257-3264.

Kehler J, Tolkunova E, Koschorz B, Pesce M, Gentile L, Boiani M, Lomeli H, Nagy A, McLaughlin KJ, Scholer HR et al. 2004 Oct4 is required for primordial germ cell survival. EMBO Reports 5 1078-1083.

Kidd T, Bland KS \& Goodman CS 1999 Slit is the midline repellent for the robo receptor in Drosophila. Cell 96 785-794.

Kirchhof N, Carnwath JW, Lemme E, Anastassiadis K, Scholer H \& Niemann H 2000 Expression pattern of Oct-4 in preimplantation embryos of different species. Biology of Reproduction 63 1698-1705.

Lea RG, Andrade LP, Rae MT, Hannah LT, Kyle CE, Murray JF, Rhind SM \& Miller DW 2006 Effects of maternal undernutrition during early pregnancy on apoptosis regulators in the ovine fetal ovary. Reproduction 131 113-124.

Legg JA, Herbert JM, Clissold P \& Bicknell R 2008 Slits and Roundabouts in cancer, tumour angiogenesis and endothelial cell migration. Angiogenesis 11 13-21.

Liu J, Zhang L, Wang D, Shen H, Jiang M, Mei P, Hayden PS, Sedor JR \& Hu H 2003 Congenital diaphragmatic hernia, kidney agenesis and cardiac defects associated with Slit3-deficiency in mice. Mechanisms of Development 120 1059-1070.
Liu D, Hou J, Hu X, Wang X, Xiao Y, Mou Y \& De Leon H 2006 Neuronal chemorepellent Slit2 inhibits vascular smooth muscle cell migration by suppressing small GTPase Rac1 activation. Circulation Research 98 480-489.

Loffler KA \& Koopman P 2002 Charting the course of ovarian development in vertebrates. International Journal of Developmental Biology $\mathbf{4 6}$ 503-510.

McLaren A 2000 Germ and somatic cell lineages in the developing gonad. Molecular and Cellular Endocrinology 163 3-9.

McNatty KP, Smith P, Hudson NL, Heath DA, Tisdall DJ, O WS \& Braw-Tal R 1995 Development of the sheep ovary during fetal and early neonatal life and the effect of fecundity genes. Journal of Reproduction and Fertility Supplement 49 123-135.

McNatty KP, Fidler AE, Juengel JL, Quirke LD, Smith PR, Heath DA, Lundy T, O'Connell A \& Tisdall DJ 2000 Growth and paracrine factors regulating follicular formation and cellular function. Molecular and Cellular Endocrinology 163 11-20.

Mehta B \& Bhat KM 2001 Slit signaling promotes the terminal asymmetric division of neural precursor cells in the Drosophila CNS. Development 128 3161-3168.

Mertsch S, Schmitz N, Jeibmann A, Geng JG, Paulus W \& Senner V 2008 Slit2 involvement in glioma cell migration is mediated by Robo1 receptor. Journal of Neuro-Oncology 87 1-7.

Morrissey C, Dallol A, Latif F, Gazdar A \& Minna JD 2004 The candidate tumour suppressor gene SLIT-2 supresses growth and induces apoptosis in lung and breast cancer (abstract). In Proceedings of the 96th Annual Meeting of the American Association of Cancer Research, Mar 2004, Orlando, FL. Philadelphia (PA): AACR, p 812. Abstract 3519.

Narayan G, Goparaju C, Arias-Pulido H, Kaufmann AM, Schneider A, Durst M, Mansukhani M, Pothuri B \& Murty VV 2006 Promoter hypermethylation-mediated inactivation of multiple Slit-Robo pathway genes in cervical cancer progression. Molecular Cancer 516.

Pesce M, Wang X, Wolgemuth DJ \& Scholer H 1998 Differential expression of the Oct-4 transcription factor during mouse germ cell differentiation. Mechanisms of Development 71 89-98.

Piper M, Georgas K, Yamada T \& Little M 2000 Expression of the vertebrate Slit gene family and their putative receptors, the Robo genes, in the developing murine kidney. Mechanisms of Development 94 213-217.

Plump AS, Erskine L, Sabatier C, Brose K, Epstein CJ, Goodman CS, Mason CA \& Tessier-Lavigne M 2002 Slit1 and Slit2 cooperate to prevent premature midline crossing of retinal axons in the mouse visual system. Neuron 33 219-232.

Prasad A, Paruchuri V, Preet A, Latif F \& Ganju RK 2008 Slit-2 induces a tumor suppressive effect by regulating beta-catenin in breast cancer cells. Journal of Biological Chemistry 283 26624-26633.

Rae MT, Palassio S, Kyle CE, Brooks AN, Lea RG, Miller DW \& Rhind SM 2001 Effect of maternal undernutrition during pregnancy on early ovarian development and subsequent follicular development in sheep fetuses. Reproduction 122 915-922.

Rae MT, Rhind SM, Fowler PA, Miller DW, Kyle CE \& Brooks AN 2002 Effect of maternal undernutrition on fetal testicular steroidogenesis during the CNS androgen-responsive period in male sheep fetuses. Reproduction $12433-39$.

Sawyer HR, Smith P, Heath DA, Juengel JL, Wakefield SJ \& McNatty KP 2002 Formation of ovarian follicles during fetal development in sheep. Biology of Reproduction 66 1134-1150.

Seeger M, Tear G, Ferres-Marco D \& Goodman CS 1993 Mutations affecting growth cone guidance in Drosophila: genes necessary for guidance toward or away from the midline. Neuron 10 409-426.

Singh RK, Indra D, Mitra S, Mondal RK, Basu PS, Roy A, Roychowdhury S \& Panda CK 2007 Deletions in chromosome 4 differentially associated with the development of cervical cancer: evidence of slit2 as a candidate tumor suppressor gene. Human Genetics 122 71-81.

Skinner MK 2005 Regulation of primordial follicle assembly and development. Human Reproduction Update 11 461-471.

Stella MC, Trusolino L \& Comoglio PM 2009 The Slit/Robo system suppresses hepatocyte growth factor-dependent invasion and morphogenesis. Molecular Biology of the Cell 20 642-657.

Stoop H, Honecker F, Cools M, de Krijger R, Bokemeyer C \& Looijenga LH 2005 Differentiation and development of human female germ cells during prenatal gonadogenesis: an immunohistochemical study. Human Reproduction 20 1466-1476. 
Tisdall DJ, Fidler AE, Smith P, Quirke LD, Stent VC, Heath DA \& McNatty KP 1999 Stem cell factor and c-kit gene expression and protein localization in the sheep ovary during fetal development. Journal of Reproduction and Fertility 116 277-291.

Traut W, Endl E, Scholzen T, Gerdes J \& Winking H 2002 The temporal and spatial distribution of the proliferation associated Ki-67 protein during female and male meiosis. Chromosoma 111 156-164.

Vargesson N, Luria V, Messina I, Erskine L \& Laufer E 2001 Expression patterns of Slit and Robo family members during vertebrate limb development. Mechanisms of Development 106 175-180.

Wartenberg H, Ihmer A, Schwarz S, Miething A \& Viebahn C 2001 Mitotic arrest of female germ cells during prenatal oogenesis. A colcemid-like, non-apoptotic cell death. Anatomy and Embryology 204 421-435.

Wong K, Park HT, Wu JY \& Rao Y 2002 Slit proteins: molecular guidance cues for cells ranging from neurons to leukocytes. Current Opinion in Genetics \& Development 12 583-591.

Wrobel KH, Bickel D \& Kujat R 1996 Immunohistochemical study of seminiferous epithelium in adult bovine testis using monoclonal antibodies against $\mathrm{Ki}-67$ protein and proliferating cell nuclear antigen (PCNA). Cell and Tissue Research 283 191-201.

Wu JY, Feng L, Park HT, Havlioglu N, Wen L, Tang H, Bacon KB, Jiang Z, Zhang X \& Rao Y 2001 The neuronal repellent Slit inhibits leukocyte chemotaxis induced by chemotactic factors. Nature 410 948-952.

Xian J, Clark KJ, Fordham R, Pannell R, Rabbitts TH \& Rabbitts PH 2001 Inadequate lung development and bronchial hyperplasia in mice with a targeted deletion in the Dutt1/Robo1 gene. PNAS 98 15062-15066.

Yuan W, Rao Y, Babiuk RP, Greer JJ, Wu JY \& Ornitz DM 2003 A genetic model for a central (septum transversum) congenital diaphragmatic hernia in mice lacking Slit3. PNAS 100 5217-5222.

Received 1 May 2009

First decision 17 June 2009

Revised manuscript received 6 October 2009

Accepted 3 November 2009 